\title{
Congruency of Mind between Lecturers and Students in Engineering Disciplines
}

\author{
Ahmad Esa \\ Faculty of Technical Education \\ Universiti Tun Hussein Onn Malaysia (UTHM) \\ 86400 Parit Raja, Batu Pahat, Johor, Malaysia \\ E-mail: ahmad@uthm.edu.my \\ Mahmad Amir Radzali \\ Faculty of Technical Education \\ Universiti Tun Hussein Onn Malaysia (UTHM) \\ 86400 Parit Raja, Batu Pahat, Johor, Malaysia \\ E-mail:mahmad@uhm.edu.my \\ Masita Misdi \\ Faculty of Technical Education \\ Universiti Tun Hussein Onn Malaysia (UTHM) \\ 86400 Parit Raja, Batu Pahat, Johor, Malaysia \\ E-mail:masita@uthm.edu.my \\ Mohd Zahri Jaafar \\ Department of Mechanical Engineering \\ Mukah Polytechnic of Sarawak \\ K.M 7.5 Oya Street, 96400 Mukah, Sarawak, Malaysia \\ E-mail: mzahri@pmu.edu.my
}

\begin{abstract}
The discrepancy of learning styles between lecturers and their students can affect academic achievements. Therefore, this study is done to identify the congruency of learning styles between lecturers and students using Gregorc Mind Style Model (1982). In addition, this study is to discover the attributes that influence the mind styles based on gender and academic specialization. Gregorc Style Delineator is (GSD) used to identify the mind styles of 269 lecturers and first year students in University Tun Hussein Onn Malaysia (UTHM), randomly and clusterely selected. Chi Square Test is used to determine the differences in mind styles of lecturers and students. T-Test and ANNOVA is also done to identify the influence of gender and academic expertise in determining mind style. This study showed that the congruency of mind styles exists between lecturers and student. The findings suggested that lecturers should consider multiple factors in gender and academic specialization for the effectiveness of teaching and learning process.
\end{abstract}

Keywords: Mind Style, Gregorc Style Delineator (GSD), Lecturers, Students 


\section{Introduction}

Students who are new to the higher learning institutions seldom realize the importance of learning skills (Habib, et al., 1994; Noordin, 1989). According to Noordin (1989), "first year students are having problems in learning" (p.3). These students are seeing difficulties in learning because they do not know their learning styles. Moreover, according to Rodolico (2002), those who do not know their learning styles, will be unsuccessful in their lives. Therefore, students should try to discover on how they should learn. Moreover, students cannot adapt to lecturers teaching styles instantaneously (Potter \& Maccaro, 2000).

There is no straightforward terminology in learning styles. Traditionally, learning styles are habits on how people expand, store and accommodate their information. To be specific, learning styles are actually a generic concept that comprises of cognitive style, personality and sensory mode (Boyd \& Murphey, 2004) that naturally becoming the dominant interest in learning (Wintergerst, et al, 2001). Learning styles are also a composition of cognitive, affective and psychological elements that indicate of how individual should interact and giving feedback on learning environment (Duff, 2000). Whenever a person displays preferences over a learning strategy, his or her individual style will immerse (Sizoo et al., 2005).

Besides students, lecturers also hold their own learning styles that are justified with their teaching styles (Brown, 2003; Thompson et. al, 2002) and they assumed that all students should be able to proceed along with their lectures (Yusof, et al; 2005). Therefore, lecturers learning styles can be detectable. Lecturers teaching styles will reflect their individual strengths and weaknesses. However, conflict will arise in the teaching and learning process, when students' learning styles are different from lecturers' teaching styles. The mismatch between students' learning styles and lecturers' teaching style is found to be constantly happening (Felder \& Hendriques, 1995).

The dissimilarity of learning styles between lecturers and students tend to create boredom, absenteeism and low motivation in students, which to the worst extreme they even dropped from school. Lecturers are facing with low grades, absenteeism, depressing class and even being hated by students (Felder \& Silverman, 1988; Felder \& Henriques, 1995). Worst still, most lecturers have no intention to teach and accommodate the complexities of students learning styles (Stitt-Gohdes et al., 1999), even though "extensively finding from previous researches have proven that lecturers' teaching styles influence students' achievement in classroom" (Miller, 2005; p.288).

Hence, this study is done to discover the congruency of learning styles between lecturer and first year students using Gregorc Mind Style Model (1982). Other objective of the study is to reveal the attributes that influence mind style based on: (a) gender and (b) specialization area.

\section{Theoretical framework of study}

According to Gregorc Mind Style Model (1982), human mind encompasses of two dimensions that can naturally accept and relate information in efficient and effective manner. The two dimensions are the perceptual qualities and the ordering qualities. Perceptual qualities are how individuals perceive and receive information while the ordering qualities are how individuals arrange information to make it applicable. The ability of perception is divided into two qualities, which are concrete and abstract. Concrete qualities enable a person to register information directly from the five senses such as audio and visual with no hidden meaning or making connections between the ideas or concepts. On the other hand, abstract qualities allow a person to visualize information using intuition and imagination, deals mostly with matters that are practical rather than physical and seem to be beyond one's feeling and viewpoint.

As for the ordering abilities, two other qualities are highlighted such as sequential and random. Sequential qualities allow the mind to organize information in a linear or systematic manner. Individuals that hold this mind pattern needs planning. Random qualities let the mind organize information in a non-linear manner and in no particular order. Individuals that have these qualities may often be able to skip steps in procedure and still produce desired results. Gregorc (1982), have gathered two continuums that centered from concrete to abstract (perceptual ability) and from sequential to random (ordering ability). This made the four mind styles combinations of the perceptual and ordering ability, which are: (i) Concrete Sequential (CS); (ii) Concrete Random (CR); (iii) Abstract Sequential (AS); and (iv) Abstract Random (AR). The Mind Styles Profile is shown in diagram 1.1(Gregorc, 1982).

According to Gould and Caswell (2006), CS individuals are equivalent to physical and hands-on structured activities and can be predicted (example: technician), while AS individuals like activities that deals a lot with reflective thinking, rationalization and intellectual connection (example: academician). Those with AR mind styles, are inclined to on physical activities that stresses on emotion and creativity (example: poet) while CR individuals are more interested in research and risky activity (example: film craftsman). Gregorc (1982) stated that no one has a pure mind style. Some people will have combination of more than one particular mind style and or bimodal. These individuals have special precedence on learning because of their flexibility in their intercommunication with lectures and learning environments.

\section{Insert Diagram 1.1 about here}




\section{Literature review}

Orr, Park, Thompson and Thompson (1999) have done a study A study has been done by Orr, Park, Thompson and Thompson (1999) regarding students' predominant learning style using Gregorc Style Delineator (GSD) on post secondary students from business education, health occupation, and trade and industry background in Arkansas. The main focus for the study was the differences in terms of work experience, academic background and gender. Their findings showed that Concrete Sequential (24\%) learning style is the dominant style for the students, followed by Concrete Random (13\%), Abstract Random (12\%) and Abstract Sequential (4\%). In addition, in the same analysis, most students were found to be bimodal (43\%), 1\% is trimodal and 3\% with no dominant learning styles at all.

Three years later, Thompson et.all (2002) has done the same study to the lecturers in the same post secondary institutes. They found that, the lecturers also embraced the same predominant style as the students which was the Concrete Sequential. Most lecturers (50\%) had a bimodal mind style that favored Concrete Sequential and Abstract Random.

Gregorc Style Delineator (GSD) had also shared a criticism on the validity of the instrument. Harasym et al. (1995) have used GSD on the Nursing students in Human Anatomy and Physiology course by comparing two factors; examination score and learning styles. Findings showed that there were no relationship between GSD and achievements of students. The researchers recommended to dicontinue using GSD as an indicator of learning styles. However, their findings indicated that learning styles should be ranked in the following order: $\mathrm{CS}>\mathrm{AR}>\mathrm{AS}>\mathrm{CR}$.

In spite of the criticism from Harasym et al. (1995), on the validity of GSD; Moss et al. (2002) have a different stance on the issue. They found connection between GSD learning styles and students' performance in agricultural economics.

Miller (2005) agreed with Moss et al. (2002). Miller (2005) had compared the Gregorc Style Delineator (GSD) with Kolb Learning Style Inventoy (LSI) in identifying students learning styles in computer based instruction. In her finding, Miller stated that students achievement was influenced by GSD while none was found to be related to Kolb LSI. Most of the students were identified as Concrete Sequential. This finding shared the same outcome with Moss et al. (2002) and Orr et al (1999).

In a study done by Gould and Caswell (2006), they identified that athletic training students carried the mind style as followed: Concrete Sequential (44.5\%) > Abstract Random (27\%) > Concrete Random (18\%) > Abstract Sequential. On the other hand, the lecturers hold the mindstyle as followed: Concrete Sequential $(58.1 \%)>$ Concrete Random $(25.6 \%)>$ Abstract Sequential (9.3\%) > Abstract Random (7\%). This finding showed that, there is a concruency in the mind style of students and lecturers, Could and Caswell also pointed out that gender factor only influenced by AS and AR mind style.

All of these findings implied that there is no concrete learning style to measure individual preferences in learning. Wintergerst et al. (2001), stated that researchers are having difficult time in trying to determine the best concept of learning styles. However, according to Gregorc (1982), each indivdual is unique and complex. Therefore one should be tested to know what is in their mind and how they learn things.

\section{Methodology}

\subsection{Case study}

Three hundred (300) questionnaires were being distributed to lecturers and students using random and clustered sampling. Only two hundred sixty nine (269) questionnaires were returned back and completely answered. From the actual sampling returned, 37 (13.8\%) were lecturers and 232 (86.2\%) were students. All samples were gathered from lecturers and students from these respective faculties: (i) Faculty of Electrical and Electronic Engineering; (ii) Faculty of Mechanical and Manufacturing Engineering; and Faculty of Technical Education. From the total respondents, $21.6 \%$ $(\mathrm{n}=58)$ was from the Faculty of Electrical and Electronic Engineering, $32.3 \%(\mathrm{n}=87)$ was from the Faculty of Mechanical and Manufacturing Engineering, and 46.1\% $(\mathrm{n}=124)$ was from Faculty of Technical Education. The distribution between gender in this study was almost equal with $50.2 \%(n=135)$ male respondents and $49.8 \%(n=134)$ respondents were female.

\subsection{Instrumentation}

Gregorc Style Delineator (GSD) (Gregorc, 2004) has been used in this study. Demography such as respondents' marital status (lecturers and students), ethnicity, expert area and gender information were also obtained from the respondents.

GSD was minimally altered in accordance to the study taken. GSD is a self-evaluation instrument that was designed to help adults to identify and recognize their own mind styles by accepting and stating information efficiently and cost-effectively (Gregorc, 1982). It contains 10 sets of words arranged in matrix and each set represents four words of the four attributions of individual mind style. Respondents were required to rank the attributes from 1 being less descriptive to 4 being the most descriptive. There was no right or wrong answer in the selection of attributes and there were not going to be the exact score in each set of words. The rearrangement of score of each questions answered by respondents will determine the mind style. Total score of 27 and above showed a dominant mind style. The average 
mind style is between 16 to 26 and a weak mind style falls between 10 to 15 . Nevertheless, respondents might be having more than one mind style that is dominant to them ( refers to bimodal or trimodal) or they might not have any mind style that is dominant to them, if their total mind style score do not even reach 27 (Gregorc, 1982).

The reliability of GSD has been tested with an internal consistency; Alpha Cronbach. The consistency was done between first test and second test through the correlation coefficient of the pre-post test. Gregorc (1982) reported that Alpha Cronbach values were between 0.89 and 0.93 and correlation coefficient between first and second test were from and 0.85 to 0.88 for the entire mind styles tested (Thompson et al., 2002).

\subsection{Data Analysis}

Descriptive statistics is used in table form that showed frequency distribution of the respondents mind style. Chi Square Test is used to identify the difference of mind style between lecturers and students. T-Test and one-way analysis of variance (ANOVA) was also convened to determine whether mind styles were influenced by gender or academic capability. For this study, all data analysis was conducted by using Statistical Package for Social Science (SPSS).

\section{Findings}

\subsection{Pre-dominant Mind Style of Lecturers and Students}

Out of the 269 respondents, $123(45.7 \%)$ is unimodal, 131 (48.7\%) is bimodal and $5(1.9 \%)$ is trimodal. Beside that, 10 (3.7\%) respondents have been identified having dominant mind styles. All lecturers are reported to have at least one mind style that is dominant (Table 1.1). In general, the highest mind style that is dominant among respondents is AS (n $=54$ or $20.1 \%$ )

For the group of lecturers, the predominant mind style is the AS, which are 15 (40.5\%) respondents are reported to have a unimodal mind style. Lecturers that have a unimodal magnitude accordingly are, CS (4 or 10.8\%), while AR and CR is $1(2.7 \%)$ respectively. The distribution of students mind style is found to be more varied. Out of the 232 students in this study, $102(44.0 \%)$ have a unimodal mind style, $116(50 \%)$ are bimodal, and $4(1.7 \%)$ are trimodal.

On the other hand, $10(4.3 \%)$ are reported not to have a dominant mind style. In general, AS has predominantly become the mind style of 39 (16.8\%) students. The "chalk and talk" style of teaching is believed to be the factor for the increasing number of AS mind style.

\subsection{Dissimilarities between Mind Style of Lecturers and Students}

In order to measure out the significance difference of mind style between lecturers and students, Chi Square Test is being used. The number of respondents that are bimodal and trimodal are grouped into unimodal such as CS, AS, AR and CR based on the respondents' mind style (Table 1.1).

From the Chi Square Test, there is a significant difference between mind style of lecturers and students $\left[\chi^{2}(3)=10.145\right.$, $\mathrm{p}=.017]$. The analysis from the standardized residual showed that lecturers tend to have AS mind style more than what is expected of them (Table 1.2).

\section{Insert Table 1.1 about here}

\section{Insert Table 1.2 about here}

\section{Insert Table 1.3 about here}

\subsection{Mind Style According to Gender}

According to Table 1.4, male score is higher in CS and AS categories and female score is higher in AR and CR categories. The T-Test indicated that there is a significant difference in AR mind style between genders. $[\mathrm{t}=-3.858, \mathrm{df}$ $=267, \mathrm{p}=.00]$.

\section{Insert Table 1.4 about here}

Further observation demonstrated that female have a tendency toward AR compared to male. For AS mind style, the mean gathered from Faculty of Electrical and Electronic Engineering (Min $=24.67 \pm 4.302)$ showed a significance difference compared to Faculty of Mechanical and Manufacturing Engineering and Faculty of Technical Education [F $(2,266)=6.384, \mathrm{p}<.05]$. ANOVA also found that the mind style is influence by both $\operatorname{AR}[\mathrm{F}(2,266)=3.480, \mathrm{p}<.05]$ and $\mathrm{CR}[\mathrm{F}(2,266)=3.324, \mathrm{p}<.05]$.

\section{Discussion and recommendation}

Findings from the study showed that both lecturers and students have a predominant AS mind style compared to the other three mind styles. This finding is not congruent with most previous researchers' findings that discover that CS is the dominant style (Gould \& Caswell, 2006; Thompson et al., 2002; Potter \& Maccaro, 2000; Orr et al., 1999; Harasym, et al. 1995). This research does not support the pioneer of the model, Gregorc (1982) since his statement indicate that generally, most individuals are CS. Collectively, the findings might signify an inaccuracy in specific population. 
However, the sequential bipolar component is still congruent with the previous findings. It can be concluded that, lecturers and students tend to teach or learn and organize information in a structured manner.

Results from the findings show some condusive remarks. Firstly, most lecturers and students are more towards AS mind style. This indicates that the lecturers and students favor lectures, intellectual experience and imagination, analytical and logical approach, rational and theoretical values.

Secondly, it should be noted that more than one-third of the lecturers (40.5\%) are AS mind style. Students mind styles are varied. Lecturers should be accountable by not going through the process of teaching and learning simply based on their mind style in view of the fact that the students that have different mind style will be left out in the process of learning.

Thirdly, in this study, more than half of the students are bimodal (50.1\%) and not many of them are trimodal (1.7\%). This finding support Gregorc (1982) claim that indicates individuals might has more than one dominant mind style or none at all. This scenario has given extra advantage to lecturers in terms of flexibility when dealing with their teaching reflection process.

Statistics shows that some students (10\%) do not even have dominant mind style. The study of Orr et al. (1999), showed the same findings, even no further explanation was discussed on the issue. These 'minority' studies did not prioritize the teaching and learning environment but was quite flexible in the environment around them. According to Gregorc (1982), these groups "have the ability to bridge with medium capacity through two dominant mind styles - ability to perceive and ability to organize" (pg 6). Therefore, psychologically these groups do not have a strong trait to use any mind style that they are comfortable at. Knowing that, it should be understood that other factors are should be taken under consideration in determining their learning styles for the benefit of active and reflective teaching.

The Chi-Square Test derived from convergent observation on dominant mind style, indicated lecturer mind style and students do not congruent with one another. This finding was interestingly translated that mind styles are influenced by academic roles. Even though lecturers and students are included in the education community, they are different in their academic roles. Traditionally, students are seen as a group of people that are learning and lecturers are viewed as the provider of information. Gould and Caswell (2006) also agree to some extent that academic roles have a direct influence on mind.

There is still a limitation for this research. The strategy and approach used by lecturers during teaching are not considered in this research. This research specifically does not differentiate the strategy and approach in teaching on students mind style. For example, a lecturer with AS mind style might not be teaching in abstract ways or in a structured organized environment. The scope of this research is limited to cognitive aspect modeled after the Gregorc Mind Style (1982). Further studies should be done to isolate the mode of teaching with style of teaching.

Some of the suggestions for further research are to urge lecturers to take some initiatives to adjust their teaching styles with students learning styles. For this research, the target respondents are the first year students. According to Habib et al. (1994) and Noordin (1989), first year students are still fresh in their exposure of learning in higher institutions. Therefore, they should be given better exposure on the concept of learning. As a start, lecturers should play a role of professional guidance by emphasizing the needs of learning based on their individual learning styles. Lecturers will have no problem in handling this matter based on the empirical study from Gregorc Mind Style Model (1982). Academicians have the tendency on the AS mind style that focus more on reflective thinking such as rational, analytical and intellectual expressions.

For this research, gender had the influence on learning styles when compared to biological factors. The result of the research also stated that, gender only had the influence on AR mid style. Female tend to have AR mind style compared to male. The finding also means that gender factor should be considered when the in congruency happens between lecturers and students. Some believe that male students do not perform well in their academics because lecturers use teaching styles that are favored by female students (Mohd Jelas et al. 2005). AR individuals are not interested in physical task but like to reflect with their emotional and harmonious surroundings. They have the ability to interact well with other people. A new learning strategy should be implemented without favoring the feminist or masculine group. A question is derived from the finding that argues: "Do the selection of certain profession are influenced by gender or mind style?"

Hence, two substantial groups emerge when comparing mind style with academic field. Generally, AS mind style is dominant over others. The groups from Faculty of Mechanical and Manufacturing Engineering and Faculty of Technical Education tend to have AS mind style. While the group from Faculty of Electrical and Electronic Engineering dominates CS mind style. This finding indicates that the group from the Faculty of Electrical and Electronic Engineering is expected to do tasks that are physically challenged, hands-on, structural and properly organized. This tendency is exactly describe the engineering students that are concrete, pragmatic and obey the rules. Therefore, these characteristics are the dominant factors that contribute to the highest score in CS domain for the Faculty of Electrical 
and Electronic Engineering. On the other hand, the group from Faculty of Mechanical and Manufacturing Engineering with the Faculty of Technical Education are more on the AS mind style that are more conceptual and analytical. However, these groups still need to follow clear, well planned and organized instruction like the group from Faculty of Electrical and Electronic Engineering.

Contextually, significant differences of mind style exist between these three faculties. However, Faculty of Technical Education is consistent with Gregorc Mind Style Model (1982) even though the other two engineering faculties have shown some contradiction between one another. This indicates that other dichotomy exist and influence the teaching and learning processes. For instance, the management style, organizational climate are the extrinsic factors that contribute to the teaching and learning process. This information is vital in providing the sources to plan teaching and learning process strategically. Some lecturers of Faculty of Electrical and Electronic Engineering are AS mind style and can teach mechanical students in intellectual and conceptual approach with abstract structure. Most electrical topics are designed with abstract characteristics.

The findings from this research indicate that most respondents and their expectations falls under the category of AS, and the consistency in teaching and learning process comes from the environment that are logical, analytical, intellectual and structured. However, collaborative activities should be encouraged so that students will work together to obtain various mind style for synergizing atmosphere. Students have the potentials to tolerate other mind style during class activities and assignments. This situation serves some advantages especially to freshmen that are still new to campus life. By experiencing various mind style in class, students will have a sense an awareness to face the challenging education world. By taking this approach as potential 'modus operandi', the Problem Based Learning (PBL) and Project Oriented Based Learning (POPBL) are, guarantee to give satisfaction in their learning.

\section{Conclusion}

Students can be responsible for their learning if they were given priority on how to decide the best way to learn. From a contradiction perspective, this should be done by analyzing their learning styles and the learning climate that condusive to learning. Being able to identify their own learning styles will enable them to access their own learning strategy. The content of the curriculum delivered by lecturers should reflect the need of multidimensional understanding on how subjects should be taught and how students should learn.

\section{References}

Bostrom, L., \& Lassen, L. M. (2006). Unraveling learning, learning styles, learning strategies and meta-cognition. Education \& Training, 48(2), 178-189.

Boyd, B. L., \& Murphey, T. P. (2004). Evaluating the scope of learning style instrument used in studies published in the journal of agricultural education. Journal of Southern Agricultural Education Research, 54(1), 124-132.

Brown, B. L. (2003). Teaching style vs. learning style. Myths and realities, (ERIC No. ED 482329). 26, 2-4.

Duff, A. (2000). Learning style of UK higher education students: Four studies of the reliability and replicability of the learning style questionnaire (LSQ). Bristol Business School Teaching and Research Review, 14(3). 131-177.

Felder, R. M., \& Henriques, E. R. (1995). Learning and teaching styles in foreign and second language education. Foreign Language Annals, 28(1), 21-31

Felder, R. M., \& Silverman, L. K. (1988). Learning and teaching styles in engineering education. Engineering Education, 78(7), 674-681.

Gould, T., E., \& Caswell, S., V. (2006). Stylistic learning difference between undergraduate athletic training students and educators: Gregorc mind style. Journal of Athletic Training, 41(1), 109-116.

Gregorc, A. F. (1982). An adult's guide to style. Columbia, CT: Gregorc Associates.

Gregorc, A. F. (2004). Gregorc style delineator: A self-assessment instrument for adults. Columbia, CT: Gregorc Associates.

Habib, A. R., Sayuti, S. and Othman, A. H. (1994). Atribusi kejayaan akademik pelajar di sebuah institusi pengajian tinggi. Jurnal Personalia Pelajar, 3(3), 97-120.

Harasym, P. H., Leong, E. J., Lucier, G. E., \& Lorscheider, F. L. (1995). Gregorc learning style and achievement in anatomy and psychology. Advance in Psychology Educatio, 13(1), 56-60.

Miller, L. M. (2005). Using learning styles to evaluate computer-based instruction. Computer in Human Behavior. 21, 287-306.

Mohd Jelas, Z., Rahman, S., Baki, R. and Ahmad, J. Prestasi akademik mengikut gender. Jurnal Pendidikan, 31, 93-111. 
Moss, L. E., Seitz, W. D., Anton, W. R. and Anton, T. E. (2002). Learning style, student-centered learning techniques, and student performance in agricultural economics". NACTA Journal. [Online] Available: http://findarticles.com/p/a/articles/mi_qa4062/is_200212/ai_n9151541 (March, 2006).

Noordin, T. A. (1989). Tinjauan masalah-masalah pembelajaran di kalangan pelajar berpencapaian rendah: Kaedah perbincangan. Jurnal Personalia Pelajar, 1, 3-9.

Orr, B., Park, O., Thompson, D. and Thompson, C. (1999). Learning style of postsecondary students enroll in vocational technical institutes, Journal of Industrial Teacher Education. 36, 5-20. [Online] Available: http://scholar.lib.vt.edu/ejournals/JITE/v36n4/orr.html. (March, 2006).

Potter, M., \& Maccaro, K. (2000). The business of teaching business. Journal of Business Education.1. [Online] Available: http://abe.villanova.edu/proc2000/n034.pdf. (August, 2006).

Rodolico, J. T. (2002). Teaching cognitive learning strategies and vocabulary testing. Hwa Kang Journal of TEFL, 8, 1-20. [Online] Available: http://www.hkjtefl.org/2002-Rodolico-Teaching.html (December, 2005).

Sizoo, S. L., Agrusa, J. F., \& Iskat, W. (2005). Measuring and developing the learning strategies of adult career and vocational education students. Education, 125(4), 527-538.

Stitt-Gohdes, W. L. (2001). Business education students' perferred learning styles. Journal of Career and Technical Education, 18(1), 32-45.

Thompson, D., Orr, B., Thompson, C. and Park, O., (2002). Preferred learning style of postsecondary technical institute instructors. Journal of Industrial Teacher Education. 39(4). [Online] Available: http://scholar.lib.vt.edu/ejournals/JITE/v39n4/thompson.html (March, 2006).

Wintergerst, A. C., DeCapua, A., \& Itzen, R. (2001). The construct validity of one learning styles instrument. System, 29, 385-403.

Yusof, R., Othman, N. and Karim, F. (2005). Strategi pembelajaran pengalaman berasaskan model Kolb dalam pendidikan perakaunan. Jurnal Pendidikan, 31, 113-128.

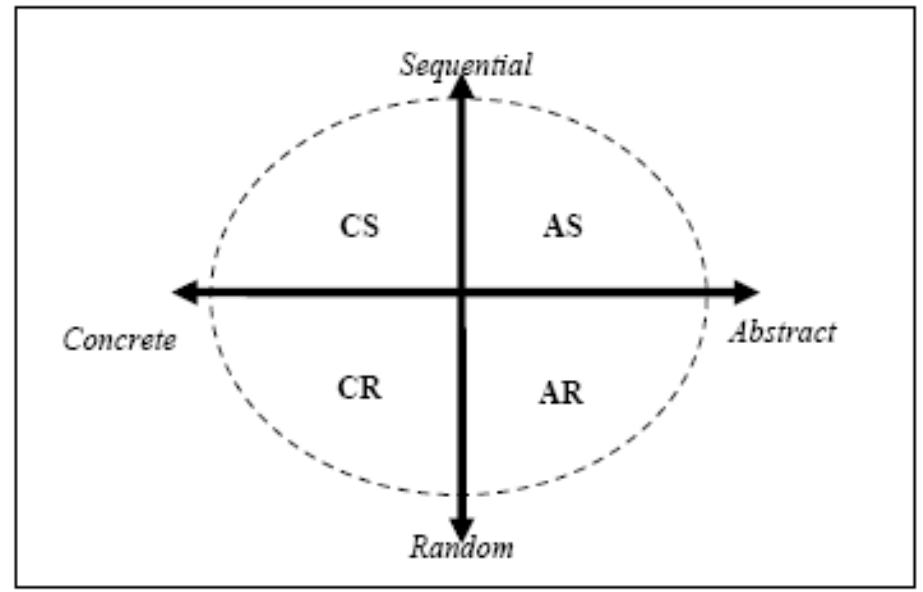

Diagram 1.1 Gregorc Mind Styles Profile (1982)

Table 1.1 Mind Style Frequencies and Percentage between Lecturers and Students

\begin{tabular}{llll}
\hline & Frequency & Total \\
Dominant Mind Style & Lecturer & Student & $\mathbf{n}$ \\
& $\mathbf{n}$ & $\mathbf{n}$ & $\mathbf{( \% )}$ \\
& $\mathbf{( \% )}$ & $\mathbf{( \% )}$ & \\
\hline $\mathrm{CS}$ & 4 & 13 & 17 \\
& $(10.8 \%)$ & $(5.6 \%)$ & $(6.3 \%)$ \\
AS & 15 & 39 & 54 \\
& $(40.5 \%)$ & $(16.8 \%)$ & $(20.1 \%)$ \\
AR & 1 & 27 & 28
\end{tabular}




\begin{tabular}{|c|c|c|c|}
\hline & $(2.7 \%)$ & $(11.6 \%)$ & $(10.4 \%)$ \\
\hline \multirow[t]{2}{*}{ CR } & 1 & 23 & 24 \\
\hline & $(2.7 \%)$ & $(9.9 \%)$ & $(8.9 \%)$ \\
\hline \multirow[t]{2}{*}{ CS-AS } & 6 & 31 & 37 \\
\hline & $(16.2 \%)$ & $(13.4 \%)$ & $(13.8 \%)$ \\
\hline \multirow[t]{2}{*}{ CS-AR } & 1 & 16 & 17 \\
\hline & $(2.7 \%)$ & $(6.9 \%)$ & $(6.3 \%)$ \\
\hline \multirow[t]{2}{*}{ CS-CR } & 1 & 13 & 14 \\
\hline & $(2.7 \%)$ & $(5.6 \%)$ & $(5.2 \%)$ \\
\hline \multirow[t]{2}{*}{ AS-AR } & 3 & 20 & 23 \\
\hline & $(8.1 \%)$ & $(8.6 \%)$ & $(8.6 \%)$ \\
\hline \multirow[t]{2}{*}{ AS-CR } & 3 & 18 & 21 \\
\hline & $(8.1 \%)$ & $(7.8 \%)$ & $(7.8 \%)$ \\
\hline \multirow[t]{2}{*}{ AR-CR } & 1 & 18 & 19 \\
\hline & $(2.7 \%)$ & $(7.8 \%)$ & $(7.1 \%)$ \\
\hline \multirow[t]{2}{*}{ AS-AR-CR } & 1 & 1 & 2 \\
\hline & $(2.7 \%)$ & $(0.4 \%)$ & $(0.7 \%)$ \\
\hline \multirow[t]{2}{*}{ CS-AS-AR } & - & 2 & 2 \\
\hline & & $(0.9 \%)$ & $(0.7 \%)$ \\
\hline \multirow[t]{2}{*}{ CS-AS-CR } & - & 1 & 1 \\
\hline & & $(0.4 \%)$ & $(0.4 \%)$ \\
\hline \multirow[t]{2}{*}{ None } & - & 10 & 10 \\
\hline & & $(4.3 \%)$ & $(3.7 \%)$ \\
\hline Total, $\mathrm{n}$ & 37 & 232 & 269 \\
\hline (\%) & $(100.0 \%)$ & $(100.0 \%)$ & $(100.0 \%)$ \\
\hline
\end{tabular}

Table 1.2 Single Category of Mind Style Frequency and Percentage

\begin{tabular}{llll}
\hline & \multicolumn{2}{c}{$\begin{array}{l}\text { Frequency } \\
\mathbf{n}\end{array}$} \\
$\begin{array}{l}\text { Dominant } \\
\text { Style }\end{array}$ & $\begin{array}{lll}\text { Mind } \\
(\mathbf{\%}) \\
\text { Lecturer }\end{array}$ & $\begin{array}{l}\text { Student } \\
\mathbf{n = 2 3 2}\end{array}$ & $\begin{array}{l}\text { Total (\%) } \\
\mathbf{n}=\mathbf{2 6 9}\end{array}$ \\
& $\mathbf{n = 3 7}$ & 76 & \\
\hline CS & 12 & $(32.8 \%)$ & 88 \\
& $(32.4 \%)$ & 112 & $(32 \%)$ \\
AS & 29 & $(48.3 \%)$ & 141 \\
& $(78.4 \%)$ & 84 & $(52.4 \%)$ \\
AR & 7 & $(36.2 \%)$ & 91 \\
& $(18.9 \%)$ & 74 & $(33.8 \%)$ \\
CR & 7 & $(31.9 \%)$ & 81 \\
& $(18.9 \%)$ & $(30.1)$ \\
\hline
\end{tabular}

Notes: Total and percentage exceed $100 \%$ due to combination of two or three mind style of bimodal or trimodal respondents. 
Table 1.3 Observed and Expected Mind Style Frequency

\begin{tabular}{lllllll}
\hline \multirow{2}{*}{ Mind Style } & $\begin{array}{l}\text { Lecturer } \\
\text { Expected }\end{array}$ & Observed & Standardized Residual & Expected & Observed & Standardized residual \\
\hline CS & 12.1 & 12 & .0 & 75.9 & 76 & .0 \\
AS & 19.3 & 29 & 2.2 & 121.7 & 112 & -.9 \\
AR & 12.5 & 7 & -1.6 & 78.5 & 84 & .6 \\
CR & 11.1 & 7 & -1.2 & 69.9 & 74 & .5 \\
\hline
\end{tabular}

Notes: Total frequency exceed the real value of respondents $(n=269)$ due to combination of two or three types of mind styles of bimodal or trimodal based on single mind style; significant level $\mathrm{p}=.05$.

Table 1.4 Mean and standard deviation of mind style and gender

\begin{tabular}{llllll}
\hline Mind Style and Gender & Mean & SD & t & P value \\
\hline CS: & & & & & \\
& Male & 25.56 & 4.756 & 1.303 & .194 \\
& Female & 24.81 & 4.681 & & \\
AS: & & & & & \\
& Male & 26.73 & 4.154 & 1.956 & .051 \\
& Female & 25.72 & 4.308 & & \\
AR: & & & & & \\
& Male & 23.79 & 3.840 & -3.858 & $.000^{*}$ \\
& Female & 25.59 & 3.798 & & \\
CR: & & & & & \\
& Male & 23.91 & 4.686 & -.422 & .673 \\
& Female & 24.13 & 3.952 & & \\
\hline
\end{tabular}

Note: Male, $\mathrm{n}=135 ;$ Female, $\mathrm{n}=134 ;{ }^{*} \mathrm{p}<.05$ (2-tailed). 